\title{
Integrated Nutrient Management of Sweet Pepper (Capsicum annuum L.) in the Mid Hills of Himachal Pradesh, India
}

\author{
Shilpa ${ }^{*}$, Shivender Thakur, Monika Sharma and A.K. Sharma \\ Department of Vegetable Science, Dr YS Parmar University of Horticulture and Forestry, \\ Nauni, Solan (HP) - 173 230, India \\ *Corresponding author
}

\section{A B S T R A C T}

\begin{tabular}{|l|}
\hline Ke y w or d s \\
Bio-inoculation, \\
INM, Organic \\
manures, PGPR, \\
Sweet pepper, Yield
\end{tabular}

\section{Introduction}

Sweet pepper (Capsicum annuum L.) was introduced in India by the Britishers in $19^{\text {th }}$ century in Shimla hills (Greenleaf, 1986) and thus, named as 'Shimla mirch'.

Fruits are non-pungent with excellent aroma, hence called 'sweet pepper' and 'bell pepper' because of its bell shaped fruit.

It is commercially grown in Himachal Pradesh, Jammu and Kashmir, Uttarakhand, Arunachal Pradesh and Darjeeling district of West Bengal during summer and as an autumn crop in Maharashtra, Karnataka, Tamil Nadu and Bihar. In Himachal Pradesh, it is extensively grown as cash crop in the subtemperate areas of Solan, Shimla, Mandi and Chamba districts during summer and rainy seasons over an area of 2.07 thousand hectares with production of 34.13 metric tonnes (Anonymous, 2016), fetching remunerative returns through 'off season' supplies to the adjoining plains.

For enhancing yield of vegetable crops, soil health is crucial factor. Enhancing soil fertility and crop productivity through use of chemical fertilizers has often negatively affected the complex system of biogeochemical cycles (Roberts, 2009). 
The potential way to decrease this negative environmental impact is to follow integrated use of mineral fertilizers and organic manures including plant growth promoting rhizobacteria/bio-fertilizers. This will in turn help to meet out the nutrient requirement of the crops as well as maintaining sustainability in terms of productivity and soil fertility. Accordingly, the present study was aimed to evolve integrated plant nutrient system for cultivation of sweet pepper in the mid hills of Himachal Pradesh.

\section{Materials and Methods}

Experiment was carried out for two years (2015 and 2016) at Dr YSP University of Horticulture and Forestry, Nauni Solan, (HP) to evolve INPS system for higher productivity, profitability and soil health. The Experimental Farm is situated at $35^{\circ} 5^{\prime} \mathrm{N}$ latitude and $77^{\circ} 11^{\prime}$ E longitude at an elevation of $1270 \mathrm{~m}$ (a m s 1) at Nauni, on Rajgarh road, about $15 \mathrm{~km}$ away from the South East of Solan city (HP). The place is characterized by mild summers and cool winters. May and June are the hottest months, while December and January are the coldest. Agro-climatically, the farm area falls in the mid hill zone of HP and is characterized by sub-temperate to sub-tropical climate with moderate rainfall (1000-1300 mm).

The experiment was laid out in RBD with 03 replicates comprising 15 combinations of inorganic and organics including PGPR viz. $\mathrm{T}_{1}: \mathrm{RPF}=(\mathrm{RDF}(100 \mathrm{~N}: 75 \mathrm{P}: 55 \mathrm{~K} \mathrm{~kg} / \mathrm{ha})+$ FYM 20 t/ha)), T $: 75 \%$ NP + VC@ 2.5 t/ha, $\mathrm{T}_{3}: 50 \% \mathrm{NP}+\mathrm{VC} @ 2.5 \mathrm{t} / \mathrm{ha}, \mathrm{T}_{4}: 75 \% \mathrm{NP}+$ EC@ 2.5 t/ha, T5: $50 \% \mathrm{NP}+\mathrm{EC} @ 2.5 \mathrm{t} / \mathrm{ha}$, $\mathrm{T}_{6}: 75 \% \mathrm{NP}+\mathrm{PGPR}, \mathrm{T}_{7}: 50 \% \mathrm{NP}+\mathrm{PGPR}$, $\mathrm{T}_{8}: 75 \% \mathrm{NP}+\mathrm{VC} @ 2.5 \mathrm{t} / \mathrm{ha}+\mathrm{PGPR}, \mathrm{T}_{9}: 50$ $\% \mathrm{NP}+\mathrm{VC} @ 2.5 \mathrm{t} / \mathrm{ha}+\mathrm{PGPR}, \mathrm{T}_{10}: 75 \% \mathrm{NP}$ + EC@ 2.5 t/ha + PGPR, T $11: 50 \% \mathrm{NP}+$ EC@ $2.5 \mathrm{t} / \mathrm{ha}+\mathrm{PGPR}, \mathrm{T}_{12}: 75 \% \mathrm{NP}+\mathrm{VC}$ and EC@ 2.5 t/ha, $\mathrm{T}_{13}: 50 \% \mathrm{NP}+\mathrm{VC}$ and EC@ 2.5 t/ha, T14: 75 \% NP + VC and EC@
$2.5 \mathrm{t} / \mathrm{ha}+\mathrm{PGPR}$ and $\mathrm{T}_{15}: 50 \% \mathrm{NP}+\mathrm{VC}$ and EC@ 2.5 t/ha + PGPR.

Bio-inoculated/un-inoculated seeds/seedlings of sweet pepper cv. 'Solan Bharpur' were soaked in culture broth of bacterium (Bacillus subtilis)/sterilized water in sterilized Petriplates for 3-4 hours before sowing/transplanting in different growing media as per treatment. Seeds were sown in the nursery on $10^{\text {th }}$ and $7^{\text {th }}$ March, and subsequently; seedlings transplanted on $21^{\text {st }} \&$ $17^{\text {th }}$ April during 2015 and 2016, respectively in the treatment plots each measuring $3.0 \mathrm{~m} \mathrm{x}$ $1.8 \mathrm{~m}$, following a spacing of $60 \mathrm{~cm} \mathrm{x} 45 \mathrm{~cm}$. The NPK fertilizers were applied through Urea, SSP and MOP, respectively. N and $\mathrm{P}$ as per treatments and full $\mathrm{K}$ were given to all the plots as basal dressing. $\mathrm{N}$ was given in three spilt doses, $1 / 3^{\text {rd }}$ as basal dressing and rest further at one month interval. Recommended dose of FYM to all the plots and the other manures (vermicompost (VC) and enriched compost (EC)) as per treatments were incorporated at the time of preparation of individual plot manually. The data were recorded on important growth; yields attributes and yield along with post-harvest soil fertility status (available NPK).

\section{Statistical Analysis}

The data recorded on various parameters were analyzed for RBD design as suggested by Gomez and Gomez (1984). The results have been interpreted on the basis of ' $F$ ' test value and critical difference (CD) was calculated at $5 \%$ level of significance

The standard error of mean (SEm) and critical difference (CD) for comparing the mean of any two treatments were computed as follows:

$\mathrm{SEm}=(\mathrm{Me} / \mathrm{r}) 1 / 2$

$\mathrm{SE}(\mathrm{d})=(2 \mathrm{Me} / \mathrm{r}) 1 / 2$ 
$\mathrm{CD}=\mathrm{SE}(\mathrm{d})$ "t" value at error degree of freedom.

\section{Results and Discussion}

\section{Plant growth and flowering}

Perusal of pooled over years data in Table 1 exhibited significantly tallest plants $(60.75$ $\mathrm{cm})$ in a plot fertilized with recommended package of fertilization (RPF) i.e. $100 \mathrm{~N}$ : $75 \mathrm{P}$ : $55 \mathrm{~K} \mathrm{~kg} / \mathrm{ha}+20 \mathrm{t} \mathrm{FYM/ha}\left(\mathrm{T}_{1}\right)$. Similarly, significantly highest number of branches (4.07) were also observed by the same treatment $\left(\mathrm{T}_{1}\right)$ which determined tallest plants $(60.75 \mathrm{~cm})$ followed by statistically equal branching (4.02) in an integrated module $\mathrm{T}_{14}$ (75\% NP+VC and EC@ 2.5 t/ha + PGPR).

Overall, next to RPF, the modules comprising of $75 \%$ of recommended inorganic (NP) with or without bio-inoculation and addition of any of the organic manures (VC, EC), recorded significantly or at least numerically higher vegetative growth vis-à-vis their counter modules receiving inorganic NP @ $50 \%$ of RPF. The enhancement of vegetative growth with higher inorganic (100 or $75 \% \mathrm{NP}$ ) may be ascribed to increased activities through organic manures and bio-inoculation, which resulted in production of growth promoting substances and improved nutrient availability for longer period throughout the crop growth and resulted in better photosynthetic activities and ultimately high biomass production (Kumar and Dhar, 2010).

In an INM study in tomato by Bagale et al., (2014), a module comprising $50 \%$ RDN + FYM 20 t/ha $+25 \%$ RDN through VC +25 $\%$ RDN through neem cake + PSB + VAM showed maximum plant height $(90.37 \mathrm{~cm})$ and number of branches per plant (15.37) as compared to the values of $74.47 \mathrm{~cm}$ and 9.27 , respectively recorded in $100 \% \mathrm{RDF}+\mathrm{FYM}$ @ 20 t/ha. Similarly, according to Kondappa et al., (2009), significantly maximum branches/ plant (33.98) in chilli were recorded through $50 \% \mathrm{RDN}+50 \% \mathrm{~N}$ through FYM + bio-fertilizer + Panchagavya and it was at par with $100 \%$ RDF + Panchagavya (30.38/plant). Besides the above studies, our results are also in concordance with the findings reported earlier by Fawzy et al., (2012), Escalona and Pire (2008) and Flores et al., (2007) in sweet pepper.

The days for inducing flowering varied from 26.90 days in $\mathrm{T}_{14}(75 \% \mathrm{NP}+\mathrm{VC}$ and EC @ $2.5 \mathrm{t} / \mathrm{ha}+\mathrm{PGPR})$ to 35.79 days (RPF). Overall, addition of new organics (VC, EC) and/or bio-inoculation with Bacillus subtilis or both as substitution for reduced inorganic (NP) significantly or at least numerically led to advancement of flowering through such modules in bell pepper. Treatment $\mathrm{T}_{14}$ which induced early flowering also harvested at least one fruit in $50 \%$ of plants in minimum number of days (62.67) along with $\mathrm{T}_{15}(50 \%$ NP + VC and EC@2.5 t/ha + PGPR) which also harvested at least one fruit from $50 \%$ of plant population in statistically similar minimum days (64.33). Overall, majority of the treatments involving inorganic (NP) at reduced concentration (75 or $50 \%$ ) in integration with new organics (VC, EC) or PGPR or both attained $\mathrm{I}^{\text {st }}$ fruit harvesting in at least $50 \%$ plant population significantly or numerically earlier than RPF $\left(T_{1}\right)$ which attained this mark in as many as 75.50 days after transplanting. The earliness in flowering and subsequent $\mathrm{I}^{\text {st }}$ fruit harvesting in integrated modules as above could be attributed to the faster enhancement of vegetative growth and storing sufficient reserved food materials for differentiation of buds into flower buds whereas, the delayed flowering by the RPF utilizing $100 \%$ NPK could be due to extended vegetative phase of the plant by the availability of inorganic nitrogen as advocated by Renuka and Sankar (2001) in tomato. 
The findings on earliness concluded in the present study are in conformity of earlier researchers viz. Despande et al., (2010), who through the inoculation of chilli seedling with Azospirillum and $16.17 \%$ reduction in nitrogen (N 125 kg/ha + FYM @ 10 t/ha) observed earliest flowering (39.96 days) and fruits maturity (66.12 days) over their RPF (N $150 \mathrm{~kg} / \mathrm{ha}+\mathrm{FYM} @ 10 \mathrm{t} / \mathrm{ha})$. In tomato, Bagale et al., (2014) recorded minimum days for $50 \%$ flowering (43.67) and first harvesting (79.10 days) from transplanting with module $50 \% \mathrm{RDN}+\mathrm{FYM} 20 \mathrm{t} / \mathrm{ha}+25 \% \mathrm{RDN}$ through vermicompost $+25 \%$ RDN through neem cake + PSB + VAM while, maximum days for $50 \%$ flowering (61.10) and first harvesting (100.10 days) were recorded in 100 $\%$ RDF+FYM @ 20 t/ha. According to Shiva et al., (2015), application of $75 \% \mathrm{~N}+$ Azospirillum sp. $+75 \% \mathrm{P}+$ Phosphobacteria $+100 \% \mathrm{~K}$ reduced the number of days to flowering (51.28 days) in paprika. However, control recorded the maximum number of days to $50 \%$ flowering (57.81 days).

According to them, the bio-fertilizers facilitate the continuous availability of nutrients during the entire life cycle of the plant. These nutrients are important constituents of nucleotides, protein, chlorophyll and enzymes involved in various metabolic activities and have direct impact on vegetative and reproductive phases of the plants.

\section{Yield attributes and yield}

The yield attributes viz. size, weight and number of fruits was significantly influenced by different INM modules under study as depicted in Table 2.

The module $\mathrm{T}_{14}$ recorded maximum fruit length $(6.10 \mathrm{~cm})$, along with other four integrated modules namely; $\mathrm{T}_{15}(6.06 \mathrm{~cm}), \mathrm{T}_{6}$ $(6.00 \mathrm{~cm}), \mathrm{T}_{2}(5.88 \mathrm{~cm})$ and $\mathrm{T}_{12}(5.87 \mathrm{~cm})$ having statistically at par fruit length.
Similarly, the maximum fruit breadth (5.26 $\mathrm{cm})$ was also recorded by the same treatment $\left(\mathrm{T}_{14}\right)$ which measured maximum fruit length and closely followed by $T_{15}(5.12 \mathrm{~cm})$ vis-àvis RPF which measured $4.81 \mathrm{~cm}$ mean width of the fruits. This increase in fruit size may be ascribed to better solubilization of insoluble or fixed $\mathrm{P}$ by the bacteria and uptake of soluble $\mathrm{P}$ by the plant (Wu et al., 2005), which accelerates the secretion of growth promoting substances resulting into elongation of fruit. Similar are the findings of Bagale et al., (2014), who reported the maximum fruit diameter $(5.50 \mathrm{~cm})$ in tomato through the combination $50 \% \mathrm{RDN}+20 \mathrm{t} \mathrm{FYM/ha}+25$ $\%$ RDN through vermicompost $+25 \% \mathrm{RDN}$ through neem cake + PSB + VAM while, their RPF (100\% RDF + 20 t/ha FYM) recorded minimum fruit diameter of $3.83 \mathrm{~cm}$. Deshpande et al., (2010) also reported that fruit size in chilli through integrated module $\mathrm{N}$ 125 kg/ha + FYM @ 10 t/ha + Azospirillum was as effective as their RPF (N $150 \mathrm{~kg} / \mathrm{ha}+$ FYM 10 t/ha).

The treatment $\mathrm{T}_{14}$ which produced highest fruit size, also observed maximum fruit weight $(54.92 \mathrm{~g})$ as presented in Table 2. The fruits harvested from $T_{12}$ and $T_{6}$ also observed statistically similar fruit weight potential (52.39 $\mathrm{g}$ and $51.51 \mathrm{~g}$, respectively) as above with $\mathrm{T}_{14}$. Overall, all the treatment modules with reduced NP (75 or $50 \%$ ), organic (VC, EC) and/or PGPR or both registered statistically higher or similar fruit weight to that of RPF $\left(\mathrm{T}_{1}\right)$ which recorded $47.92 \mathrm{~g}$ weight per fruit.

As for fruit number, significantly maximum fruits per plant (27.23) were also harvested from the plant grown under the organic, inorganic and bio-inoculated combination $\mathrm{T}_{14}$. The other module which scored significantly more number of fruits over the RPF was $\mathrm{T}_{6}$ (75\% NP + PGPR), with a score of 24.59 fruits per plant. 
The analysis of variance was calculated as follows

\begin{tabular}{|l|c|c|c|c|}
\hline $\begin{array}{l}\text { Source of } \\
\text { Variation }\end{array}$ & df & $\begin{array}{c}\text { Sum of } \\
\text { Square }\end{array}$ & $\begin{array}{c}\text { Mean Sum of } \\
\text { Square }\end{array}$ & $\begin{array}{c}\text { Variance Ratio } \\
\text { ("6/9" Value) }\end{array}$ \\
\hline Replication $(\mathrm{r})$ & $(\mathrm{r}-1)$ & $\mathrm{Sr}$ & $\mathrm{Sr} /(\mathrm{r}-1)=\mathrm{Mr}$ & $\mathrm{Mr} / \mathrm{Me}$ \\
\hline Treatment $(\mathrm{t})$ & $(\mathrm{t}-1)$ & $\mathrm{St}$ & $\mathrm{St} /(\mathrm{t}-1)=\mathrm{Mt}$ & $\mathrm{Mt} / \mathrm{Me}$ \\
\hline Error & $(\mathrm{r}-1)(\mathrm{t}-1)$ & $\mathrm{Se}$ & $\mathrm{Se} /(\mathrm{r}-1)(\mathrm{t}-1)=\mathrm{Me}$ & \\
\hline
\end{tabular}

Where,

$\mathrm{r}=$ Number of replications

$\mathrm{t}=$ Number of treatments

$\mathrm{Me}=$ Mean sum of square due to error

$\mathrm{df}=$ Degree of freedom

Table.1 Effect of different INM treatments on plant growth and flowering

\begin{tabular}{|c|c|c|c|c|c|c|c|c|c|c|c|c|}
\hline \multirow{2}{*}{$\begin{array}{c}\text { Treatmen } \\
\text { t Code }\end{array}$} & \multicolumn{3}{|c|}{ Plant height (cm) } & \multicolumn{3}{|c|}{ No of primary branches } & \multicolumn{3}{|c|}{ Days to $50 \%$ flowering } & \multicolumn{3}{|c|}{ Days to $1^{\text {st }}$ harvest } \\
\hline & 2015 & 2016 & Pooled & 2015 & 2016 & Pooled & 2015 & 2016 & Pooled & 2015 & 2016 & Pooled \\
\hline$\overline{T_{1}}$ & 65.10 & 56.40 & 60.75 & 4.53 & 3.60 & 4.07 & 34.84 & 36.73 & 35.79 & 78.67 & 72.33 & 75.50 \\
\hline$\overline{T_{2}}$ & 60.79 & 52.40 & 56.60 & 3.87 & 3.47 & 3.67 & 29.50 & 32.87 & 31.18 & 69.33 & 65.67 & 67.50 \\
\hline$\overline{T_{3}}$ & 54.57 & 50.52 & 52.54 & 2.87 & 3.13 & 3.00 & 30.73 & 34.87 & 32.80 & 71.00 & 68.00 & 69.50 \\
\hline$\overline{T_{4}}$ & 52.35 & 51.15 & 51.75 & 3.47 & 3.13 & 3.30 & 30.97 & 35.53 & 33.25 & 71.33 & 69.33 & 70.33 \\
\hline$T_{5}$ & 49.23 & 50.15 & 49.69 & 3.00 & 3.33 & 3.17 & 33.23 & 36.73 & 34.98 & 76.67 & 70.00 & 73.33 \\
\hline$T_{6}$ & 62.81 & 53.00 & 57.91 & 3.73 & 3.33 & 3.53 & 27.27 & 33.93 & 30.60 & 66.00 & 65.33 & 65.67 \\
\hline$\overline{T_{7}}$ & 59.33 & 50.30 & 55.12 & 3.93 & 3.13 & 3.53 & 28.17 & 34.17 & 31.17 & 67.67 & 67.67 & 67.67 \\
\hline$\overline{T_{8}}$ & 60.26 & 51.52 & 55.89 & 3.07 & 3.27 & 3.17 & 31.43 & 32.83 & 32.13 & 73.00 & 66.33 & 69.67 \\
\hline$T_{9}$ & 55.77 & 47.99 & 51.88 & 3.00 & 2.87 & 2.93 & 29.83 & 34.47 & 32.15 & 71.00 & 69.00 & 70.00 \\
\hline$\overline{T_{10}}$ & 56.95 & 50.96 & 53.95 & 3.60 & 3.53 & 3.57 & 28.33 & 28.33 & 28.33 & 69.33 & 64.67 & 67.00 \\
\hline$T_{11}$ & 50.29 & 48.90 & 49.59 & 2.80 & 3.27 & 3.03 & 33.73 & 30.87 & 32.30 & 75.00 & 69.33 & 72.17 \\
\hline$T_{12}$ & 60.59 & 54.41 & $\mathbf{5 7 . 5 0}$ & 3.33 & 3.57 & 3.45 & 30.73 & 30.90 & 30.82 & 71.00 & 69.00 & 70.00 \\
\hline$\overline{T_{13}}$ & 53.22 & 51.98 & 52.60 & 3.20 & 3.32 & 3.26 & 30.13 & 31.57 & 30.85 & 69.33 & 68.00 & 68.67 \\
\hline$T_{14}$ & 63.15 & 54.83 & 58.99 & 4.47 & 3.57 & 4.02 & 25.90 & 27.90 & 26.90 & 66.00 & 59.33 & 62.67 \\
\hline $\mathbf{T}_{15}$ & 54.46 & 52.68 & 53.57 & 3.87 & 3.53 & 3.70 & 26.53 & 28.33 & 27.43 & 67.67 & 61.00 & 64.33 \\
\hline Mean & 57.26 & 51.81 & 54.56 & 3.52 & 3.34 & 3.43 & 30.09 & 32.67 & 31.38 & 70.87 & 67.00 & 68.93 \\
\hline C.D $D_{(0.05)}$ & 3.08 & 2.03 & 1.44 & 0.34 & 0.25 & 0.23 & 2.96 & 1.83 & 1.92 & 5.82 & 3.93 & 3.65 \\
\hline
\end{tabular}


Table.2 Effect of different INM treatments on yield attributes and yield

\begin{tabular}{|c|c|c|c|c|c|c|c|c|c|c|c|c|c|c|c|}
\hline \multirow{2}{*}{$\begin{array}{c}\text { Treatment } \\
\text { Code }\end{array}$} & \multicolumn{3}{|c|}{ Fruit length (cm) } & \multicolumn{3}{|c|}{ Fruit breadth (cm) } & \multicolumn{3}{|c|}{ Fruit weight (g) } & \multicolumn{3}{|c|}{ Number of fruits per plant } & \multicolumn{3}{|c|}{ Yield per hectare } \\
\hline & 2015 & 2016 & Pooled & 2015 & 2016 & Pooled & 2015 & 2016 & Pooled & 2015 & 2016 & Pooled & 2015 & 2016 & Pooled \\
\hline $\mathbf{T}_{1}$ & 4.75 & 5.91 & 5.33 & 17.94 & 21.80 & 19.87 & 43.53 & 52.30 & 47.92 & 17.94 & 21.80 & 19.87 & 230.60 & 290.63 & 260.62 \\
\hline$\overline{T_{2}}$ & 5.73 & 6.03 & 5.88 & 19.55 & 24.13 & 21.85 & 48.27 & 52.23 & 50.25 & 19.55 & 24.13 & 21.85 & 290.68 & 324.68 & 307.68 \\
\hline$\overline{T_{3}}$ & 5.11 & 5.90 & 5.51 & 17.44 & 21.60 & 19.52 & 45.47 & 49.17 & 47.32 & 17.44 & 21.60 & 19.52 & 228.71 & 285.47 & 257.09 \\
\hline $\mathbf{T}_{4}$ & 4.94 & 5.72 & 5.33 & 17.05 & 23.20 & 20.13 & 44.10 & 54.40 & 49.25 & 17.05 & 23.20 & 20.13 & 232.44 & 309.51 & 270.98 \\
\hline$T_{5}$ & 4.40 & 5.66 & 5.03 & 15.72 & 21.60 & 18.66 & 43.06 & 52.20 & 47.63 & 15.72 & 21.60 & 18.66 & 221.21 & 280.82 & 251.02 \\
\hline$\overline{T_{6}}$ & 6.04 & 5.96 & 6.00 & 23.77 & 25.40 & 24.59 & 48.98 & 54.03 & 51.51 & 23.77 & 25.40 & 24.59 & 329.30 & 314.61 & 321.95 \\
\hline $\mathbf{T}_{7}$ & 5.85 & 5.76 & 5.81 & 19.61 & 20.60 & 20.11 & 47.68 & 49.53 & 48.61 & 19.61 & 20.60 & 20.11 & 281.13 & 256.26 & 268.70 \\
\hline $\mathbf{T}_{8}$ & 5.59 & 5.96 & 5.78 & 20.83 & 20.07 & 20.45 & 47.33 & 47.57 & 47.45 & 20.83 & 20.07 & 20.45 & 305.69 & 341.81 & 323.75 \\
\hline $\mathrm{T}_{9}$ & 5.23 & 5.68 & 5.46 & 18.72 & 19.67 & 19.20 & 46.14 & 46.30 & 46.22 & 18.72 & 19.67 & 19.20 & 248.28 & 277.45 & 262.87 \\
\hline $\mathrm{T}_{10}$ & 5.28 & 5.90 & 5.59 & 16.72 & 22.87 & 19.79 & 46.98 & 50.83 & 48.91 & 16.72 & 22.87 & 19.79 & 235.38 & 311.25 & 273.31 \\
\hline$\overline{T_{11}}$ & 4.46 & 5.81 & 5.14 & 15.83 & 19.67 & 17.75 & 43.70 & 52.20 & 47.95 & 15.83 & 19.67 & $\mathbf{1 7 . 7 5}$ & 203.58 & 251.64 & 227.61 \\
\hline$T_{12}$ & 5.63 & 6.10 & 5.87 & 18.55 & 24.07 & 21.31 & 47.67 & 57.10 & 52.39 & 18.55 & 24.07 & 21.31 & 267.85 & 335.38 & 301.62 \\
\hline $\mathbf{T}_{13}$ & 4.96 & 5.96 & 5.46 & 16.39 & 23.80 & 20.09 & 44.69 & 53.20 & 48.95 & 16.39 & 23.80 & 20.09 & 229.60 & 308.25 & 268.93 \\
\hline $\mathrm{T}_{14}$ & 6.06 & 6.13 & 6.10 & 26.05 & 28.40 & 27.23 & 50.37 & 59.47 & 54.92 & 26.05 & 28.40 & 27.23 & 371.01 & 364.34 & 367.68 \\
\hline $\mathrm{T}_{15}$ & 6.04 & 6.08 & 6.06 & 21.05 & 24.40 & 22.73 & 48.54 & 52.20 & 50.37 & 21.05 & 24.40 & 22.73 & 311.88 & 315.44 & 313.66 \\
\hline Mean & 5.34 & 5.90 & 5.62 & 19.01 & 22.75 & 20.89 & 46.34 & 52.18 & 49.31 & 19.01 & 22.75 & 20.89 & 265.82 & 304.50 & 285.16 \\
\hline C. $D_{(0.05)}$ & 0.43 & 0.28 & 0.26 & 2.74 & 2.66 & 1.90 & 1.70 & 6.63 & 3.42 & 2.74 & 2.66 & 1.90 & 26.47 & 28.12 & 20.43 \\
\hline
\end{tabular}

Table.3 Effect of different INM treatments on available NPK

\begin{tabular}{|c|c|c|c|c|c|c|c|c|c|}
\hline \multirow{2}{*}{$\begin{array}{c}\text { Treatment } \\
\text { Code }\end{array}$} & \multicolumn{3}{|c|}{ Available nitrogen $(\mathrm{kg} / \mathrm{ha})$} & \multicolumn{3}{|c|}{ Available phosphorus $(\mathrm{kg} / \mathrm{ha})$} & \multicolumn{3}{|c|}{ Available potassium (kg/ha) } \\
\hline & $\mathbf{2 0 1 5}$ & $\mathbf{2 0 1 6}$ & $\mathbf{P o o l e d}$ & $\mathbf{2 0 1 5}$ & $\mathbf{2 0 1 6}$ & Pooled & $\mathbf{2 0 1 5}$ & $\mathbf{2 0 1 6}$ & Pooled \\
\hline $\mathrm{T}_{\mathbf{1}}$ & 314.59 & 317.54 & $\mathbf{3 1 6 . 0 7}$ & 34.27 & 35.71 & $\mathbf{3 4 . 9 9}$ & 399.54 & 390.59 & $\mathbf{3 9 5 . 0 7}$ \\
\hline $\mathrm{T}_{2}$ & 333.46 & 338.67 & $\mathbf{3 3 6 . 0 7}$ & 39.75 & 42.32 & $\mathbf{4 1 . 0 4}$ & 412.10 & 418.60 & $\mathbf{4 1 5 . 3 5}$ \\
\hline $\mathrm{T}_{3}$ & 298.97 & 293.67 & $\mathbf{2 9 6 . 3 2}$ & 36.63 & 36.31 & $\mathbf{3 6 . 4 7}$ & 409.45 & 400.80 & $\mathbf{4 0 5 . 1 3}$ \\
\hline $\mathrm{T}_{4}$ & 296.16 & 305.16 & $\mathbf{3 0 0 . 6 7}$ & 29.24 & 35.21 & $\mathbf{3 2 . 2 3}$ & 400.57 & 407.51 & $\mathbf{4 0 4 . 0 4}$ \\
\hline $\mathrm{T}_{\mathbf{5}}$ & 297.92 & 290.56 & $\mathbf{2 9 4 . 2 4}$ & 21.36 & 23.02 & $\mathbf{2 2 . 1 9}$ & 384.77 & 357.81 & $\mathbf{3 7 1 . 2 9}$ \\
\hline $\mathrm{T}_{6}$ & 390.82 & 349.71 & $\mathbf{3 7 0 . 2 7}$ & 43.94 & 45.39 & $\mathbf{4 4 . 6 7}$ & 447.47 & 419.15 & $\mathbf{4 3 3 . 3 1}$ \\
\hline $\mathrm{T}_{7}$ & 380.44 & 338.25 & $\mathbf{3 5 9 . 3 5}$ & 40.80 & 44.41 & $\mathbf{4 2 . 6 1}$ & 431.06 & 398.99 & $\mathbf{4 1 5 . 0 3}$ \\
\hline $\mathrm{T}_{\mathbf{8}}$ & 375.89 & 371.56 & $\mathbf{3 7 3 . 7 3}$ & 44.10 & 48.64 & $\mathbf{4 6 . 3 7}$ & 417.40 & 420.53 & $\mathbf{4 1 8 . 9 7}$ \\
\hline $\mathrm{T}_{9}$ & 311.49 & 317.83 & $\mathbf{3 1 4 . 6 6}$ & 39.09 & 42.15 & $\mathbf{4 0 . 6 3}$ & 401.49 & 409.62 & $\mathbf{4 0 5 . 5 6}$ \\
\hline $\mathrm{T}_{10}$ & 313.59 & 322.10 & $\mathbf{3 1 7 . 8 5}$ & 40.14 & 44.84 & $\mathbf{4 2 . 4 9}$ & 402.84 & 415.08 & $\mathbf{4 0 8 . 9 6}$ \\
\hline $\mathrm{T}_{11}$ & 286.56 & 271.55 & $\mathbf{2 7 9 . 0 6}$ & 23.84 & 24.07 & $\mathbf{2 3 . 9 6}$ & 383.65 & 395.70 & $\mathbf{3 8 9 . 6 8}$ \\
\hline $\mathrm{T}_{12}$ & 379.45 & 352.52 & $\mathbf{3 6 5 . 9 9}$ & 42.43 & 43.98 & $\mathbf{4 3 . 3 6}$ & 421.88 & 424.00 & $\mathbf{4 2 3 . 4 4}$ \\
\hline $\mathrm{T}_{13}$ & 310.47 & 300.23 & $\mathbf{3 0 5 . 3 5}$ & 37.68 & 37.90 & $\mathbf{3 7 . 7 9}$ & 407.76 & 405.82 & $\mathbf{4 0 6 . 7 9}$ \\
\hline $\mathrm{T}_{14}$ & 418.13 & 382.42 & $\mathbf{4 0 0 . 2 8}$ & 51.87 & 53.36 & $\mathbf{5 2 . 6 1}$ & 464.37 & 447.78 & $\mathbf{4 5 6 . 0 7}$ \\
\hline $\mathrm{T}_{15}$ & 378.17 & 344.82 & $\mathbf{3 6 1 . 4 9}$ & 43.88 & 42.71 & $\mathbf{4 3 . 3 0}$ & 443.68 & 411.25 & $\mathbf{4 2 7 . 4 7}$ \\
\hline $\mathrm{Mean}_{\mathbf{n}}$ & 339.07 & 326.44 & $\mathbf{3 3 2 . 7 6}$ & 37.93 & 40.00 & $\mathbf{3 8 . 9 8}$ & 415.20 & 408.22 & $\mathbf{4 1 1 . 7 4}$ \\
\hline $\mathrm{CD}_{(0.05)}$ & $\mathbf{2 3 . 5 8}$ & $\mathbf{1 7 . 6 0}$ & $\mathbf{1 5 . 6 5}$ & $\mathbf{5 . 4 5}$ & $\mathbf{6 . 6 8}$ & $\mathbf{4 . 8 0}$ & $\mathbf{1 3 . 5 3}$ & $\mathbf{1 5 . 4 4}$ & $\mathbf{8 . 2 3}$ \\
\hline
\end{tabular}


Table.4 Effect of different treatments on economics of sweet pepper

\begin{tabular}{|c|c|c|c|c|c|}
\hline Treatment code & $\begin{array}{c}\text { Yield } \\
\text { (t/ha) }\end{array}$ & $\begin{array}{c}\text { Gross return (Rs. } \\
\text { in lacs) }\end{array}$ & $\begin{array}{c}\text { Cost of cultivation } \\
\text { (Rs in lacs) }\end{array}$ & $\begin{array}{c}\text { Net return } \\
\text { (Rs. in lacs) }\end{array}$ & B: C ratio \\
\hline $\mathrm{T}_{1}$ & 26.06 & 4.64 & 1.30 & 3.18 & 2.16 \\
\hline $\mathrm{T}_{2}$ & 30.77 & 5.43 & 1.67 & 3.61 & 1.96 \\
\hline $\mathrm{T}_{3}$ & 25.71 & 4.57 & 1.63 & 2.78 & 1.51 \\
\hline $\mathrm{T}_{4}$ & 27.01 & 4.84 & 1.37 & 3.32 & 2.13 \\
\hline $\mathrm{T}_{5}$ & 25.10 & 4.47 & 1.24 & 3.02 & 2.05 \\
\hline $\mathrm{T}_{6}$ & 32.20 & 5.62 & 1.32 & 4.14 & 2.79 \\
\hline $\mathrm{T}_{7}$ & 26.87 & 4.67 & 1.31 & 3.21 & 2.04 \\
\hline $\mathrm{T}_{8}$ & 32.38 & 5.71 & 1.71 & 3.84 & 1.49 \\
\hline $\mathrm{T}_{9}$ & 26.29 & 4.64 & 1.69 & 2.79 & 1.06 \\
\hline $\mathrm{T}_{10}$ & 27.33 & 4.88 & 1.41 & 3.31 & 2.17 \\
\hline $\mathrm{T}_{11}$ & 22.76 & 4.04 & 1.38 & 2.50 & 1.86 \\
\hline $\mathrm{T}_{12}$ & 30.16 & 5.36 & 1.52 & 3.69 & 2.73 \\
\hline $\mathrm{T}_{13}$ & 26.89 & 4.80 & 1.51 & 3.15 & 2.25 \\
\hline $\mathrm{T}_{14}$ & 36.77 & 6.43 & 1.56 & 4.71 & 0.22 \\
\hline $\mathrm{T}_{15}$
\end{tabular}

The module $\mathrm{T}_{14}$ statistically excelled the RPF $(260.62 \mathrm{q} / \mathrm{ha})$ as well as all the other integrated modules with an yield outlay of $367.68 \mathrm{q} / \mathrm{ha}$. The treatment combination $\mathrm{T}_{6}$ (75\% NP + PGPR) even without any compensation by way of any organics for reduced synthetic content seems to have worked well as evident through its $3^{\text {rd }}$ highest record of yield (321.95 q/ha) after $\mathrm{T}_{14}$ and $\mathrm{T}_{8}$. In general, the increase in yield was more pronounced primarily in vermicompost related modules vis-a-vis those supplemented with enriched compost with or without bioinoculation. Overall, six integrated modules viz. $\mathrm{T}_{14}, \mathrm{~T}_{8}, \mathrm{~T}_{6}, \mathrm{~T}_{15}, \mathrm{~T}_{2}$, and $\mathrm{T}_{12}$ exerted highest positive influence on yield and yielding attributes which significantly surpassed RPF comprising $100 \%$ inorganic (NPK) along with $20 \mathrm{t} \mathrm{FYM/ha}\left(\mathrm{T}_{1}\right)$. The increased yield of $41.08,24.22,23.53,20.35$, 18.06 , and 15.73 per cent, respectively observed by above modules was primarily on account of increase in components of yield viz. fruit size, weight, numbers as well as early harvest. The findings suggested that by the end of $2^{\text {nd }}$ year of crop raising, reduction of at least $25 \%$ recommended inorganic (NP) is possible through their substitution primarily with VC and/or bio-inoculation of planting material with Bacillus subtilis.

The higher yielding attributes and yield of capsicum through treatments supplemented with vermicompost alone or along with enriched compost in the present study could also be the result of regulated liberalization and balanced supply of nutrients, tilting microbial dynamics in favour of growth and creation of salutary soil environmental conditions for crop growth. In addition, besides its better nutrient contents, it could have increased the efficiency of added chemical fertilizers by its temporary immobilization, which reduces leaching of plant nutrients (Das et al., 2006). Further, the PGPR can provide biologically fixed nitrogen to plants by meeting requirement up to $15-20$ $\mathrm{kg} \mathrm{N} / \mathrm{ha}$ and secretes beneficial growth promoting substances like IAA, GA, kinetin, riboflavin, and thiamine, which can result in better plant growth (Malik et al., 2005).

Corroborating with the results of present investigation, Khan et al., (2008) showed that use of Azotobacter, Azospirillum in conjunction with $75 \%$ RDN recorded 
significant increase in growth and yield of chillies as compared to control and concluded that $\mathrm{N}$-fixing bio fertilizers could reduce the use of inorganic nitrogen by 25-50 per cent. Dass et al., (2008) observed higher number as well more fruit weight of bell pepper and consequently the significantly higher yield from the plot treated with $50 \% \mathrm{RPF}+5 \mathrm{t} / \mathrm{ha}$ $\mathrm{VC}$ and $50 \% \mathrm{RPF}+\mathrm{VC} @ 2.5 \mathrm{t} / \mathrm{ha}+\mathrm{CM} @$ $5 \mathrm{t} / \mathrm{ha}$ than recommended rate of synthetic fertilizers(NPK). Rani et al., (2015) also recorded higher green chilli yield on account of higher fruit number and weight when 150 $\%$ of recommended dose of nitrogenous fertilizer was sourced half through inorganic and another half from organic sources viz. FYM $(25 \%)$ and Neem Cake $(25 \%)$ as basal and vermicompost as top dressing $(50 \%)$.

The reasons for increased fruit yield in chilli were attributed to the increased solubilization effect and availability of nutrient by the addition of organics and increased physiological activity leading to the build up of sufficient food reserves for the developing sinks and better portioning towards the developing fruits.

The advantage on yield by following different combinations of treatments by the integrated nutrition have also been reported in sweet pepper/chilli by Singh et al., (2009), Talukder and Jana (2009) and Lal and Kanaujia (2013).

\section{Available NPK}

The significantly maximum available $\mathrm{N}$ $(400.28 \mathrm{Kg} / \mathrm{ha})$ was through the module comprising of $75 \% \mathrm{NP}+\mathrm{VC}$ and EC @ 2.5 $\mathrm{t} / \mathrm{ha}+$ PGPR $\left(\mathrm{T}_{14}\right)$ which was followed by $\mathrm{T}_{8}$ (75\% NP + VC@ $2.5 \mathrm{t} / \mathrm{ha}+\mathrm{PGPR})$ and $\mathrm{T}_{6}$ (75\% NP + PGPR), recording 373.73 and $370.27 \mathrm{~kg} \mathrm{~N} / \mathrm{ha}$, respectively. The gain in nitrogen availability in soil through above three treatment modules was to the tune of 26.64, 18.24 and 17.15 per cent, respectively over the RPF i.e. $T_{1}(316.07 \mathrm{~kg} / \mathrm{ha})$. As far phosphorus, $\mathrm{T}_{14}$ and $\mathrm{T}_{8}$ again registered significantly maximum mean P i.e. 52.61 and $46.37 \mathrm{~kg} / \mathrm{ha}$, respectively, among all modules including RPF (34.99 $\mathrm{kg} \mathrm{P/ha).} \mathrm{The}$ availability of these macro-nutrients was more pronounced when reduction in recommended inorganic application was substituted primarily with vermicompost, PGPR or both. The mean content of $\mathrm{K}$ was also maximum (456.07 kg/ha) with $\mathrm{T}_{14}$ closely followed by $\mathrm{T}_{6}, \mathrm{~T}_{15}$, and $\mathrm{T}_{2}$ which recorded 433.31, 427.47 and $423.44 \mathrm{~kg} \mathrm{P} / \mathrm{ha}$, respectively (Table 3 ).

Concluding, in our study, conjoint use of organic manures particularly vermicompost, PGPR and chemical fertilizers could result in saving of at least $25 \%$ of synthetic fertilizers (NP) which is in conformity with conclusion drawn by many earlier researchers as below.

Prativa and Bhattarai (2011) obtained the maximum available $\mathrm{N}, \mathrm{P}$ and $\mathrm{K}$ to be 382.80 , 100.40 and $230.80 \mathrm{~kg} / \mathrm{ha}$, respectively after harvesting tomato, when half of recommended NPK was integrated with 15 t/ha vemicompost as compared to $1 / 2 \mathrm{NPK}+$ 30 t/ha FYM which recorded $350.80,88.70$ and $193.60 \mathrm{~kg}$ of $\mathrm{N}, \mathrm{P}$ and $\mathrm{K}$, respectively or absolute recommended synthetic fertilizer (340.00, 89.30 and $184.10 \mathrm{~kg}$, respectively).

They explained that mixing of $\mathrm{N}$ fertilizer with organic manures (more importantly VC) might have reduced the nitrogen losses, improved the fertilizer use efficiency thus increasing the availability of $\mathrm{N}$.

The increase in phosphorus is attributable to the fact that vermicompost in combination with synthetic fertilizers might have helped in the solubilization of fixed $\mathrm{P}$ to soluble form making it easily available to the plant whereas, high availability of $\mathrm{K}$ might be due to enhancement in $\mathrm{K}$ availability by shifting the equilibrium among the form of $\mathrm{K}$ from 
relatively exchangeable $\mathrm{K}$ to soluble $\mathrm{K}$ forms in the soil.

\section{Economic}

The economic analysis showed that the highest net return of Rs 4.71 lacs by incurring Rs.1.56 lacs towards cost of cultivation per hectare was obtained from treatment $\mathrm{T}_{14}(75$ $\% \mathrm{NP}+\mathrm{VC}$ and EC @ $2.5 \mathrm{t} / \mathrm{ha}+\mathrm{PGPR})$ on account of highest yield (36.77 t/ha) with a benefit: cost ratio of 2.73 .

However, the benefit: cost ratio was highest (2.79) through module $\mathrm{T}_{6}(75 \% \mathrm{NP}+\mathrm{PGPR})$ which otherwise recorded lesser yield (32.20 t/ha) as well as net returns (Rs. 4.14 lacs) visà-vis to the former module i.e. $\mathrm{T}_{14}$.

This was 'in fact' on account of additional cost incurred on organic inputs (VC, EC) used in $\mathrm{T}_{14}$.

However, it is pertinent to mention here that $\mathrm{T}_{14}$ vis-a-vis $\mathrm{T}_{6}$ also resulted in good build-up of nutrient status (NPK) in soil as envisaged through Table 4.

Patil et al., (2016), noticed the highest B: C ratio (7.77) case of $100 \%$ RDF treatment visà-vis $50 \% \mathrm{RDF}+25 \% \mathrm{~N}$ through FYM and $25 \%$ as through $\mathrm{VC}$ (5.93) to a carrot crop, yet the net returns were almost comparable between the former (Rs 1,24,286/-) and later one (Rs 1,23,738/-).

Similar returns through conjoint use of organic manures, PGPR/biofertilizers and chemical fertilizers has also been reported by Talukder and Jana (2009), Vimera et al., (2012) in chilli and Lal and Kanaujia (2013) and Rani et al., (2015) in capsicum.

Concluding, the integrated module $\mathrm{T}_{14}(75 \%$ $\mathrm{NP}+\mathrm{VC}$ and EC @ 2.5 t/ha + PGPR) along with full recommended potash and FYM as basal application which resulted in saving of $25 \%$ fertilizers (NP), better growth, higher yield and net returns along with enhanced soil health, can be suggested as a cost effective combination for getting higher yield of sweet pepper on sustainable basis.

\section{References}

Anonymous. NHB. 2016. National Horticulture Board Database. www.nhb.gov.in

Bagale, M. M., Kale, V. S., Khardeand, R. P. and Alekar, A. N. 2014. Integrated nutrient management studies in tomato. Bioinfolet 11: 1054-7.

Das, A., Prasad, M., Gautam, R. C. and Shivay, Y. S. 2006. Productivity of cotton (Gossypium hirsutum) as influenced by organic and inorganic sources of nitrogen. Indian Journal of Agricultural Sciences 76: 354-7.

Dass, A., Lenka, N. K., Patnaik, U. S. and Sudhishri, S. 2008. Integrated nutrient management for production, economics and soil improvement in winter vegetables. Int J Veg Sci 14: 104-20.

Deshpande, R. P., Tamgadge, S., Deshmukh, A. and Deshmukh, S. 2010. Effect of organic and inorganic manures on growth and yield of chilli. Int $J$ Forestry \& Crop Improvement 1: 146-8.

Escalona, A. and Pire, R. 2008. Growth and N$\mathrm{P}-\mathrm{K}$ removal in chicken manure fertilized bell pepper (Capsicum annuum L.) plants in Quibor, Lara State, Venezuela. Revista de la Faculated de Agronomia, Universidad del Zulia. 25: 243-60.

Fawzy, Z. F., El-Bassiony, A. M., Yunsheng, Li., Zhu, O. and Ghoname, A. A. 2012. Effect of mineral, organic and bio-N fertilizers on growth, yield and fruit quality of sweet pepper. J Applied Sci Res 8(8): 3921-33.

Flores, P., Castellar, I., Hellin, P., Fenoll, J. and Navarro, J. 2007. Response of pepper plants to different rates of mineral fertilizers after soil biofumigation and solarization. J Plant Nutrition 30: 367-79. 
Greenleaf, W. H. 1986. Pepper breeding. (In) Breeding Vegetable Crops. AVI, West Port, pp. 67-134.

Khan, M. A., Zarghar, Y. and Ara, S. 2008. Performance of carrier-based inoculants in some vegetable crops grown in Srinagar, Kashmir. J Plant Sci Res 24(2): 215-7.

Kondapa, D., Radder, B. M., Patil, P. L., Hebsur, N. S. and Alagundagi, S. C. 2009. Effect of integrated nutrient management on growth, yield and economics of chilli (cv. Byadgi Dabba) in a vertisol. Karnataka J Agri Sci 22: 43840.

Kumar, A. and Dhar, S. 2010. Evaluation of organic and inorganic sources of nutrients in maize (Zea mays) and their residual effect on wheat (Triticum aestivum) under different fertility levels. Indian J Agri Sci 80: 364-71.

Lal, S. and Kanaujia, S. P. 2013. Integrated nutrient management in capsicum under low cost polyhouse condition. Annals of Hort 6: 170-7.

Malik, B. S., Paul, S., Sharma, R. K., Sethi, A. P. and Verma, O. P. 2005. Effect of Azotobacter chroococcum on wheat (Triticum aestivum) yield and its attributing components. Indian J Agri Sci 75: 600-2.

Prativa, K. C. and Bhattarai, B. P. 2011. Effect of integrated nutrient management on the growth, yield and soil nutrient status in tomato. Nepal J Sci \& Tech 12: 23-8.

Rani, P. L., Balaswamy, K., Rao, A. R. and Masthan. S. C. 2015. Evaluation of integrated nutrient management practices on growth, yield and economics of green chilli cv. Pusa Jwala (Capsicum annuum
L.). Int $J$ Bio-resource \& Stress Management 6: 076-80.

Renuka, B. and Ravi Shankar, C. 1998. Effect of organic manures on growth and yield of tomato. South Indian Horti 49: 216-7.

Roberts, T. L. 2009. The role of fertilizer in growing the world's food. Better Crops 93: $12-5$.

Shiva, K. N., Srinivasan, V., Zachariah, T. J. and Leela, N. K. 2015. Integrated nutrient management on growth, yield and quality of paprika alike chillies (Capsicum annuum L.). J Spices \& Aromatic Crops 24: $92-7$.

Singh, A., Singh, K. G. and Gosal, S. K. 2009. Integrated nutrient management in sweet pepper (Capsicum annuum L. var. grossum) grown in naturally ventilated polyhouse. Department of Microbiology, PAU, Ludhiana 36: 171-4.

Taludker, B. and Jana, J. C. 2009. Integrated nutrient management for better growth, yield and quality of green chilli (Capsicum annuum L.) in Tarai region of West Bengal. Indian J Agri Sci 79: 600-3.

Vimera, K., Kanaujia, S. P., Singh, V. B. and Singh, P. K. 2012. Effect of integrated nutrient management on growth and yield of king chilli under foothill condition of Nagaland. J Indian Soci of Soil Sci 60: 45-9.

Wu, S. C., Cao, Z. H., Li, Z. G., Cheung, K. C. and Wong, M. H. 2005. Effects of biofertilizer containing $\mathrm{N}$-fixer, $\mathrm{P}$ and $\mathrm{K}$ solubilizers and AM fungi on maize growth: a greenhouse trial. Geoderma 125: $155-66$.

\section{How to cite this article:}

Shilpa, Shivender Thakur, Monika Sharma and Sharma, A.K. 2018. Integrated Nutrient Management of Sweet Pepper (Capsicum annuum L.) in the Mid Hills of Himachal Pradesh, India. Int.J.Curr.Microbiol.App.Sci. 7(03): 952-961. doi: https://doi.org/10.20546/ijcmas.2018.703.113 